\title{
A sister for the Mathematical Gazette
}

\section{PETER REYNOLDS}

In the 1960s, the Gazette was the only journal of the Association. It often appeared to members who were teaching in schools and involved in the quite turbulent changes that were taking place that the Gazette was out of touch with their needs and written for an élitist audience of university and sixth-form teachers. In contrast, the Association of Teachers of Mathematics produced an increasingly popular and lively magazine Mathematics Teaching which did write about classroom teaching and was in stark contrast to the slightly fuddy-duddy Gazette.

For readers too young to have taught in the $1960 \mathrm{~s}$, it is difficult to appreciate the carefree and confident mood of the times. Expansion to meet the growing school population meant that there was plenty of money for books, equipment and innovation. Education was not in the spotlight as it is today even though the introduction of comprehensive schools in many areas was causing problems of adjustment especially for former grammar-school teachers who discovered that there were pupils even less able than any bottom set they had ever taught!

The curriculum was changing too. Modern mathematics was in vogue. The School Mathematics Project (SMP) had begun its massive rise to dominance from small beginnings in 1961. But these changes were often changes in mathematical content such as replacing any remaining bits of Euclidean geometry by an intuitive 'motion geometry' (reflections, rotations, shears, etc.) or by vectors in the case of another innovative scheme, the Midlands Mathematical Experiment (MME). Little discussion took place about teaching styles which were largely drill and practice.

Although the school leaving age was 15 , an increasing number of pupils were staying on at school and for many of them the GCE O level examination was too difficult and unsuitable. In 1965 a new Certificate of Secondary Education (CSE) started its short life (doomed because it was required to link with $O$ level at Grade 1 and so was forced into the top-down curriculum which was so heavily criticized by the Cockcroft report in 1982). Even so, the introduction of CSE resulted in a lot of curriculum development and new assessment procedures since coursework was an option. All of these changes required much support and guidance.

There were other quite serious problems. In prosperous times with full employment, mathematics graduates were not attracted to teaching with its modest salaries and so there was a growing shortage of qualified teachers to cope with the ever growing school population. This was particularly true of girls' schools and many girls left school having been badly taught by nonspecialist teachers or, equally disastrously, having given up mathematics at the age of fourteen. It was this kind of pressure, especially in the large cities, which led to the creation later of individualised learning schemes in which 
pupils could use materials designed to work in the absence of qualified specialist mathematics teachers.

Readers of the Gazette could be blissfully unaware of these changes and pretend that nothing had happened. There were, of course, the odd references such as Mrs Williams' presidential address, in the October 1966 issue, entitled The changing role of mathematics in education. Secondary teachers could flick through these pages, assuring themselves that the changes were largely at primary level anyway, and move on to the more interesting articles such as The use of the axiomatic method in secondary teaching or The distance of a 'random chord' of a circle from the centre. Probably fewer than $10 \%$ of articles in the Gazette were concerned directly with teaching as opposed to mathematics.

It was not surprising, therefore, that Mathematics Teaching (MT) under the creative editorship of Claude Birtwistle, sometimes using photographs and colour effectively, appeared to meet the average teacher's needs rather better than the Gazette. For example, the autumn 1966 issue of MT contained an article by David Sturgess on 'What matters?' in which he reflected on the new projects such as SMP. Many of the articles in the same issue were about practical activities, equipment and apparatus to be used in the classroom but often linked to a theoretical and mathematical background. MT contained articles about issues that teachers in the classroom, who were looking for support and guidance through an interesting but challenging period, needed.

By 1970, the Mathematical Association decided that it too needed a journal which was more closely related to the classroom and, to my surprise; I was invited by Douglas Quadling, then editor of the Gazette, to start Mathematics in School.

It was a wonderful opportunity. I was given a free hand and no firm guidelines were laid down but a larger format magazine was indicated. Many magazines at that time, including MT, used a now little used paper size called Crown quarto (about $10 \times 7 \frac{1}{2}$ inches) but an increasing number were beginning to use the larger international paper size A4. It was decided that Mathematics in School (MiS) would use A4 paper which provides greater scope for designing pages. Longman Journals, the first publisher of MiS, employed a designer who provided a new front cover design for each issue and laid out the pages in an attractive and eye-catching style. It was not possible to confuse its appearance with the Gazette!

The first issue was in November 1971. What happened after that, and whether MiS did meet the challenge of providing the service that members needed, is for others to judge. It certainly allowed the Gazette to focus clearly on sixth-form and early undergraduate mathematics.

PETER REYNOLDS, President 1989-90

6 Rosebery Road, Felixstowe IPII 7JR 